Vol. 11 (2002): 199-207.

\title{
Sodium reduction in cooked meat products by using commercial potassium phosphate mixtures
}

\author{
Marita Ruusunen \\ Department of Food Technology, PO Box 27 (Viikki E), FIN-00014 University of Helsinki, Finland, \\ e-mail: marita.ruusunen@helsinki.fi \\ Markku Niemistö \\ Meat Research Centre, PO Box 56 (Luukkaankatu 8), FIN-13101 Hämeenlinna, Finland \\ Eero Puolanne \\ Department of Food Technology, PO Box 27 (Viikki E), FIN-00014 University of Helsinki, Finland
}

\begin{abstract}
In addition to salt $(\mathrm{NaCl})$, sodium phosphate also increases the sodium content of meat products. Thus, the effects of replacing sodium phosphate with potassium phosphate on sodium content and properties of low-salt cooked bologna-type sausage and cooked ham were studied. Four sausage formulations were prepared. In formulations 1 and 2 , the target sodium content was $0.55 \mathrm{~g} \mathrm{Na} / 100 \mathrm{~g}$, and in recipes 3 and 4, $0.63 \mathrm{~g} \mathrm{Na} / 100 \mathrm{~g}$. The salt content in formulation 2 was the same as in formulation 3 , namely $1.2 \% \mathrm{NaCl}$, but the sodium content in the former was lower. In the cooked hams of recipes 1 and 2, the salt content was $1.4 \%$, and in recipes 3 and $4,1.8 \%$. Sodium phosphate was used in recipes 1 and 3, and potassium phosphate in recipes 2 and 4. Very low-salt (i.e. $1.0-1.4 \% \mathrm{NaCl}$ ) meat products can be prepared providing that phosphates are added. Further reduction of sodium content in low-salt meat products is possible by replacing sodium phosphate with potassium phosphate. The extent of sodium reduction depends on the phosphates used and their sodium content, being equivalent to a sodium content of $0.2 \% \mathrm{NaCl}$ or more. The replacement resulted in no adverse effects. Alkaline phosphates are also recommended in very low-salt products to minimize risk of purge.
\end{abstract}

Key words: sausages, ham, salt, sodium reduction, phosphates

\section{Introduction}

Phosphates are important functional additives in meat products. They are generally used to enhance water-binding capacity and to improve cooking yield. This is brought about by an increase in the $\mathrm{pH}$ of the meat from its isoelectric point and enhanced ionic strength (Hamm 1972, Trout and Schmidt 1987). Many phosphates are suitable for use in meat products, sodium tripolyphosphate (STPP) being most common 


\section{Ruusunen, M. et al. Sodium reduction in cooked meat products}

(Barbut et al. 1988). STPP increases stability of reduced salt meat emulsions (Knipe et al. 1990). According to Knipe et al. (1985), tetrasodium and tetrapotassium pyrophosphates resulted in higher raw meat emulsion $\mathrm{pH}$, protein solubility, emulsion stability and water-holding capacity than sodium or potassium tripolyphosphate. Shults et al. (1972, 1973) studied the ability of different phosphates to reduce shrink and increase water retention in intact beef and chicken. The authors reported that pyrophosphate increases swelling and reduces shrink most effectively, followed by tripolyphosphate and ortophosphate.

Phosphate enhances the effect of added salt (Shults et al. 1972, Whiting 1984, Trout and Schmidt 1986, Puolanne et al. 2001), and good water and fat binding can be reached at a lowsalt content (about 1.5\%; Puolanne and Ruusunen 1983). Besides its influence on $\mathrm{pH}$ and ionic strength, phosphate has a specific effect on myofibrillar proteins by cleaving the actomyosin bond (Hamm 1972, Offer and Knight 1988). Although both salt and phosphates lead to an increase in water-holding capacity and protein solubility in meat, the mechanisms are different. As noted by Lewis (1979), TPP (tripolyphosphate) alone dissolves the entire Z-disc region, while $\mathrm{NaCl}$ induces losses in the I-band. A combination of both TPP and $\mathrm{NaCl}$ results in disruption throughout the sarcomere.

The addition of phosphates to processed meats has become standard practice (Sofos 1986, Trout and Schmidt 1987). The maximum amount of phosphates permitted in meat products is $0.5 \%$ $\mathrm{P}_{2} \mathrm{O}_{5}$ (EU Directive 95/2/EY). Concern over the health aspects of excessive sodium consumption, particularly from table salt (sodium chloride), has led to efforts to find ways to simultaneously retain the desirable characteristics of processed meats while radically reducing sodium content. A reduction in the sodium content of processed meat products can be accomplished in several different ways: 1 . reducing $\mathrm{NaCl}$ content, 2. replacing some or all of the $\mathrm{NaCl}$ with another chloride salt, 3. replacing sodium-containing additives with corresponding non-sodium addi- tives. Phosphates have been investigated as a partial alternative to sodium chloride, permitting the production of low-sodium processed meat. After sodium chloride, sodium phosphate is, however, the second highest source of sodium in meat products. Most sodium phosphates contain about $30 \%$ sodium.

The objective of this study was to examine the sodium reduction of cooked bologna-type sausage and cooked ham by replacing sodium phosphate with potassium phosphate. This study is part of a project aimed at a reduction in sodium content of meat products.

\section{Material and methods}

\section{Sausage preparation}

Sausages were made from lean pork (fat content $12 \%$ ), pork fat (fat content $89 \%$ ) and pork skin. Salt, nitrite, phosphate, ascorbic acid, sodium caseinate, soya concentrate and spices as well as water and ice were added. The sausages were processed with common manufacturing methods.

The phosphates used included a sodium diphosphate mixture $\left(59 \% \mathrm{P}_{2} \mathrm{O}_{5}, 30 \% \mathrm{Na}\right)$ and tetrapotassium pyrophosphate $\left(43 \% \mathrm{P}_{2} \mathrm{O}_{5}\right)$. The $\mathrm{pH}$ values of the $1 \%$ sodium diphosphate mixture solution and the tetrapotassium pyrophosphate solution were 8.70 and 10.44 , respectively.

Four formulations were prepared. In formulations 1 and 2, the target sodium content was $0.55 \mathrm{~g} \mathrm{Na} / 100 \mathrm{~g}$, and in recipes 3 and 4, $0.63 \mathrm{~g}$ $\mathrm{Na} / 100 \mathrm{~g}$. The $\mathrm{NaCl}$ content in formulation 1 was $1.0 \%$, and in formulation $4,1.4 \%$. The $\mathrm{NaCl}$ content in formulation 2 was the same as in formulation 3 , namely $1.2 \% \mathrm{NaCl}$, but the sodium content in the former was lower. The amounts of sodium derived from $1 \%$ sodium chloride (in product $393 \mathrm{mg} \mathrm{Na} / 100 \mathrm{~g}$ ) and $0.25 \%$ sodium phosphate mixture (in product $75 \mathrm{mg} \mathrm{Na} / 100 \mathrm{~g}$ ) were calculated based on molecular weight. The amount of sodium derived from other ingredi- 
Vol. 11 (2002): 199-207.

ents (in product $82 \mathrm{mg} \mathrm{Na} / 100 \mathrm{~g}$ ) was evaluated based on our preliminary experiments.

The batters were stuffed into an impermeable casing (diameter $80 \mathrm{~mm}$ ) and cooked for 180 min at $76^{\circ} \mathrm{C}$ to achieve an endpoint product temperature of $72^{\circ} \mathrm{C}$ and then cooled in a cold shower for $40 \mathrm{~min}$. After cooling, the sausages were vacuum-packaged and stored at $3^{\circ} \mathrm{C}$. Each of the sausage formulations was made twice.

\section{Ham preparation}

In the cooked hams of recipes 1 and 2 , salt content was $1.4 \%$, and in recipes 3 and $4,1.8 \%$. A sodium phosphate mixture (sodium di-, tri- and polyphosphates, 57.4\% $\mathrm{P}_{2} \mathrm{O}_{5}$ ) was used in recipes 1 and 3, and a potassium phosphate mixture (potassium diphosphate and sodium monophosphate, $43.6 \% \mathrm{P}_{2} \mathrm{O}_{5}$ ) in recipes 2 and 4 . The $\mathrm{pH}$ values of the $1 \%$ sodium phosphate solution and the $1 \%$ potassium phosphate solution were 8.52 and 9.20 , respectively. The lower salt level of $1.4 \%$ was chosen on the basis of earlier experiments (Ruusunen et al. 2000), where the ham made with $1.4 \%$ added salt did not differ, based on cooking loss, from hams made with higher salt levels.

The $\mathrm{pH}$ value of pork trimmings (fat content $12 \%$ ) was 5.61 . The trimmings were ground through $13 \mathrm{~mm}$ plates. The brine solution for each formulation was prepared by dissolving the phosphate mixture, followed by ascorbic acid, sodium nitrite and sodium chloride in tap water $\left(2^{\circ} \mathrm{C}\right)$. The brine was added to ground ham in a vacuum tumbler. The hams (each 9.60 to 9.65 $\mathrm{kg}$ ) were massaged in a vacuum for $2 \mathrm{~h}$ and kept overnight at $3^{\circ} \mathrm{C}$. The next day, the hams were stuffed into a $90-\mathrm{mm}$ casings. For each formulation, four 1.4-kg hams were obtained. The hams were thermally processed (Vemag Verdener Maschinen- und Apparatebau GMBH, Germany) to a core meat temperature of $72^{\circ} \mathrm{C}$ by using a stepwise thermal processing schedule (drying: $10 \mathrm{~min}$ at $55^{\circ} \mathrm{C}, 12 \mathrm{~min}$ at $60^{\circ} \mathrm{C}$ and $12 \mathrm{~min}$ at $65^{\circ} \mathrm{C}$; smoking: $12 \mathrm{~min}$ at $68^{\circ} \mathrm{C}$; cooking: $50 \mathrm{~min}$ at $72^{\circ} \mathrm{C}$ and $100 \mathrm{~min}$ at $77^{\circ} \mathrm{C}$; cooling $59 \mathrm{~min}$ in a cold shower). Each of the ham formulations was made twice.

\section{pH measurement}

The $\mathrm{pH}$ values of the sausage batters and cooked sausages as well as of the ham batters and cooked hams were measured directly with a Xerolyte electrode (Ingold Xerolyt LoT406-M6, Inlab 427, Mettler Toledo GmbH, Germany).

\section{Chemical analysis}

Moisture content was determined by drying the sample at $104^{\circ} \mathrm{C}$ for $16 \mathrm{~h}$. Protein content was determined by the Kjeldahl method (NMKL 1976). $\mathrm{NaCl}$ concentration was determined by analysing chloride-ion content (Corning 926 Chloride Analyser, Corning Medical and Scientific Corning Limited, England). Sodium content was analysed with an Na-selective electrode (Ross ${ }^{\mathrm{TM}}$ sodium electrode, Orion Research Inc.) (Kivikari 1996).

\section{Water-binding analyses}

Purge loss (\%) in vacuum-packaged sausages was obtained by measuring the amount of juice released when the sausages were stored for four days at $4^{\circ} \mathrm{C}$. The sausages were peeled, and the amount of juice released was collected and weighed. The amount of juice was expressed as a percentage. Only one sausage from each formulation was weighed.

Cooking loss in cooked hams was determined by weighing all hams of the same formulation together before cooking and $3 \mathrm{~h}$ after cooking. The cooking loss was expressed as a percentage.

Water-binding capacity of cooked ham was determined with a centrifugation method (Hamm 1962). Thirty grams of massaged raw ham was weighed and placed in a centrifuge tube. The tubes were heated for $25 \mathrm{~min}$ in a $75^{\circ} \mathrm{C}$ water 


\section{Ruusunen, M. et al. Sodium reduction in cooked meat products}

bath until the inside temperature was $72^{\circ} \mathrm{C}$, cooled $45 \mathrm{~min}$ at a temperature of $4^{\circ} \mathrm{C}$, centrifuged at $3000 \mathrm{rpm}$ for $10 \mathrm{~min}$ at a temperature of $20^{\circ} \mathrm{C}$ and then the liquid was drained. After this, the tubes were weighed again, and the centrifugation loss was calculated as the difference in weight before and after centrifugation. Water-binding capacity was expressed as g water/ $100 \mathrm{~g}$ meat. Five replications were made of each ham formulation.

\section{Sensory evaluation}

The sausages and hams were evaluated by using a hedonic scale. The panelists evaluated appearance by a three-point, texture by a five-point and taste and flavour by a seven-point scale. The panel consisted of ten experts who routinely evaluate meat products. All were familiar with the product type and its range of variation. Each panelist assigned points to every product. The panelists then had a discussion session, and based on this, assigned one value to each sausage and ham.

The triangle test (Amerine et al. 1965) was used to detect differences caused by replacing sodium phosphate with potassium phosphate. Sausages 1 and 2 and sausages 3 and 4 were compared. Hams 1 and 2 and hams 3 and 4 were also compared. The panel consisted of 19 assessors, who were members of the laboratory sensory panel and advanced meat technology students, all with previous training in using the triangle test. The sausage and ham samples were presented in slices of $0.5 \mathrm{~cm}$ thickness. Samples were presented in random order. Assessors evaluated both the sausages and the hams twice.

\section{Statistical analysis}

The data were analysed using the SAS program (SAS Institute Inc. 1989). Differences in properties of sausages and hams were studied using two-way analysis of variance. The two factors were replication and sausage/ham. A Tukey test with the significance level set at $\mathrm{P}=0.05$ was used to determine differences.

The triangle test was used to detect any differences in products as a result of replacing sodium phosphate with potassium phosphate. The significance of distinguishing between samples was established based on the number of correct judgements according to Amerine et al. (1965).

\section{Results and discussion}

\section{Chemical composition of sausages and hams}

The moisture content of the sausages was $66.8 \pm$ $0.9,67.4 \pm 0.4,67.2 \pm 0.6$ and $67.3 \pm 0.6 \%$, the fat content $18.5 \pm 0.6,18.2 \pm 0.5,17.9 \pm 0.6$ and $18.0 \pm 0.6 \%$, and the protein content $13.4 \pm 0.6$, $12.8 \pm 0.3,12.6 \pm 0.2$ and $12.6 \pm 0.3 \%$, respectively. Sodium contents in sausage 1 and 2 , and in 3 and 4 were the same, $0.56 \mathrm{~g} \mathrm{Na} / 100 \mathrm{~g}$ and $0.63 \mathrm{~g} \mathrm{Na} / 100 \mathrm{~g}$, respectively (Table 1).

The moisture content of the hams was $76.6 \pm$ $0.1,76.8 \pm 0.2,76.7 \pm 0.1$ and $76.3 \pm 0.2 \%$, the fat content $3.3 \pm 0.4,2.6 \pm 0.1,2.5 \pm 0.2$ and $2.8 \pm 0.1 \%$, and the protein content $18.5 \pm 0.6$, $18.1 \pm 0.6,17.9 \pm 0.5$ and $18.4 \pm 0.4 \%$, respectively. Salt content in hams 1 and 2 as well as in hams 3 and 4 was the same, but due to the use of potassium phosphate in hams 2 and 4 , sodium content in the former was lower than in ham 1, and in the latter lower than in ham 3. In hams 2 and 4 , the sodium content was $0.13 \mathrm{~g} \mathrm{Na} / 100 \mathrm{~g}$ lower than in hams 1 and 3 (Table 1).

\section{Purge loss in sausages as well as cooking loss and water-binding capacity of hams}

The $\mathrm{pH}$ values of batters (sausages 2 and 4) made with the potassium phosphate mixture were higher than those (sausages 1 and 3) made with the sodium phosphate $(\mathrm{P}<0.05)$ (Table 1$)$. Prepara- 
Vol. 11 (2002): 199-207.

Table 1. $\mathrm{pH}$ values of batters, sausages and hams; salt $(\mathrm{NaCl})$ and sodium content of sausages and hams; purge loss (\%) of sausages; and cooking loss and water-binding capacity of hams.

\begin{tabular}{|c|c|c|c|c|c|c|c|}
\hline & Batter, $\mathrm{pH}$ & Sausage, $\mathrm{pH}$ & $\mathrm{NaCl}, \%$ & $\begin{array}{l}\text { Sodium, } \\
\mathrm{g} / 100 \mathrm{~g}\end{array}$ & $\begin{array}{c}\text { Purge loss, } \\
\%\end{array}$ & $\begin{array}{c}\text { Cooking loss, } \\
\%\end{array}$ & $\begin{array}{c}\text { Water-binding } \\
\text { capacity, } \\
\text { g water } / 100 \mathrm{~g} \\
\text { meat }\end{array}$ \\
\hline \multicolumn{8}{|l|}{ Sausages ${ }^{1)}$} \\
\hline Sausage 1 & $5.91 \pm 0.02^{\mathrm{b}}$ & $6.19 \pm 0.06^{\mathrm{a}}$ & $1.1 \pm 0.04^{\mathrm{c}}$ & $0.56 \pm 0.02^{\mathrm{b}}$ & $2.3 \pm 1.8^{\mathrm{a}}$ & & \\
\hline Sausage 2 & $6.19 \pm 0.01^{\mathrm{a}}$ & $6.34 \pm 0.05^{\mathrm{a}}$ & $1.3 \pm 0.04^{\mathrm{b}}$ & $0.57 \pm 0.02^{b}$ & $0.0 \pm 0.0^{\mathrm{a}}$ & & \\
\hline Sausage 3 & $5.94 \pm 0.01^{\mathrm{b}}$ & $6.19 \pm 0.04^{\mathrm{a}}$ & $1.3 \pm 0.03^{b}$ & $0.63 \pm 0.01^{\mathrm{a}}$ & $0.0 \pm 0.0^{\mathrm{a}}$ & & \\
\hline Sausage 4 & $6.17 \pm 0.03^{a}$ & $6.34 \pm 0.04^{a}$ & $1.4 \pm 0.04^{\mathrm{a}}$ & $0.63 \pm 0.02^{\mathrm{a}}$ & $0.0 \pm 0.0^{\mathrm{a}}$ & & \\
\hline \multicolumn{8}{|l|}{$\mathrm{Hams}^{2)}$} \\
\hline Ham 1 & $5.76 \pm 0.08^{\mathrm{d}}$ & $5.99 \pm 0.01^{\mathrm{d}}$ & $1.3 \pm 0.04^{\mathrm{e}}$ & $0.73 \pm 0.02^{\mathrm{e}}$ & & $2.6 \pm 1.1^{\mathrm{d}}$ & $8.0 \pm 4.3^{\mathrm{f}}$ \\
\hline Ham 2 & $5.93 \pm 0.04^{\mathrm{d}}$ & $6.10 \pm 0.02^{\mathrm{d}}$ & $1.3 \pm 0.01^{\mathrm{e}}$ & $0.60 \pm 0.02^{\mathrm{f}}$ & & $2.7 \pm 1.1^{\mathrm{d}}$ & $11.0 \pm 5.2^{\mathrm{e}}$ \\
\hline Ham 3 & $5.82 \pm 0.02^{\mathrm{d}}$ & $6.04 \pm 0.06^{\mathrm{d}}$ & $1.6 \pm 0.01^{\mathrm{d}}$ & $0.89 \pm 0.04^{\mathrm{d}}$ & & $2.8 \pm 1.1^{\mathrm{d}}$ & $12.6 \pm 3.4^{\mathrm{de}}$ \\
\hline Ham 4 & $5.95 \pm 0.08^{d}$ & $6.09 \pm 0.02^{\mathrm{d}}$ & $1.7 \pm 0.01^{\mathrm{d}}$ & $0.76 \pm 0.03^{\mathrm{e}}$ & & $2.8 \pm 1.0^{\mathrm{d}}$ & $14.8 \pm 1.9^{\mathrm{d}}$ \\
\hline
\end{tabular}

a,b,c same letter in the column means no significant difference between sausages

d,e,f same letter in the column means no significant difference between hams

Sausages $^{1)}$ : Sausage 1, $1.0 \% \mathrm{NaCl}+$ sodium diphosphate mixture; Sausage 2, $1.2 \% \mathrm{NaCl}+$ tetrapotassium pyrophosphate; Sausage 3, $1.2 \% \mathrm{NaCl}+$ sodium diphosphate mixture; Sausage 4, $1.4 \% \mathrm{NaCl}+$ tetrapotassium pyrophosphate

$\mathrm{Hams}^{2)}$ : Ham 1, 1.4\% NaCl + sodium phosphate mixture; Ham 2, 1.4\% $\mathrm{NaCl}+$ potassium phosphate mixture; Ham 3, $1.8 \%$ $\mathrm{NaCl}+$ sodium phosphate mixture; Ham $4,1.8 \% \mathrm{NaCl}+$ potassium phosphate mixture

tion of the sausage with $1.0 \% \mathrm{NaCl}$ and $0.25 \%$ sodium phosphate mixture caused purge (Table 1). This was the only sausage where purge was found. When the sodium content was the same $(0.57 \mathrm{~g} \mathrm{Na} / 100 \mathrm{~g}$, sausage 2$)$, but the sausage was prepared with $1.2 \% \mathrm{NaCl}$ and the potassium phosphate mixture, no purge loss was found (Table 1). An explanation for this may be the latter sausages higher salt content, the use of more alkaline phosphate and pyrophosphate mixture. Pyrophosphates improve water-holding capacity better than tripolyphosphates (Knipe et al. 1985). Our findings show that in less optimal systems, such as in meat products with very low salt content, the addition of alkaline pyrophosphate may result in beneficial effects on texture and water-binding capacity. Similarly, Rust and Olson (1982) pointed out that the use of alkaline phosphates may be the most practical alternative when reducing salt content in processed meats. Moreover, Keeton et al. (1984) found an increased firmness in sausages containing alkaline phosphate. In our study, the added salt content in formulation 2 was the same as in formulation $3,1.2 \%$, but the sodium content in the former was $0.06 \mathrm{~g} \mathrm{Na} / 100 \mathrm{~g}$ lower (Table 1). No purge was found in these sausages.

Cooking loss between the hams did not differ significantly $(\mathrm{P}>0.05)$ (Table 1$)$. By using the potassium phosphate mixture in ham 2 , the water-binding capacity was increased as compared with ham 1, where a sodium phosphate mixture was used $(\mathrm{P}<0.05)$ (Table 1$)$. In hams prepared with $1.8 \%$ salt (hams 3 and 4 ), no difference in water-binding capacity was found $(\mathrm{P}>$ 0.05). Using potassium phosphate combined with a higher $\mathrm{pH}$, instead of sodium phosphate with a lower $\mathrm{pH}$, resulted in better water-binding capacity at a salt content of $1.4 \%$, although sodium content was $0.13 \mathrm{~g} \mathrm{Na} / 100 \mathrm{~g}$ lower. The $\mathrm{pH}$ values of $1 \%$ sodium phosphate solution and potassium phosphate solution used in ham prep- 


\section{Ruusunen, M. et al. Sodium reduction in cooked meat products}

aration (8.52 and 9.20, respectively) were closer to each other than those used in sausage preparation (8.70 and 10.44 , respectively). Also the composition of phosphates used in hams was more similar than the composition of phosphates in sausages.

\section{Appearance, texture and taste of sausages and hams}

No difference was found in the taste and flavour of sausages $(P>0.05)$ (Table 2). Because the taste of potassium salts is bitter, these can cause off-flavour in meat products. In this study, however, no significant weakening was found in the taste and flavour of sausages made with the potassium phosphate mixture (Table 2).

No significant differences in appearance or texture were observed between the hams $(\mathrm{P}>$ 0.05 ) (Table 2). At higher salt concentrations, the effect of phosphate on texture was not as remarkable as at the lower salt concentration of $1.4 \%$, as evidenced in Table 1 in the water-binding capacity of hams. Neither did the taste and flavour differ between hams $(\mathrm{P}>0.05)$ (Table 2).

\section{The triangle test}

The taste of potassium phosphates is bitter and can cause off-flavour in products. The triangle test was therefore used to see whether any differences could be distinguished between the sausages or the hams. Sausages 1 and 2, and 3 and 4 were compared separately. When sausages 1 and 2 were compared, 27 out of 38 judgements were correct, and the corresponding figure for sausages 3 and 4 was 20 out of 38 judgements (Table 3). The differences were significant, i.e. the assessors could distinguish the sausages made with sodium phosphate from those made with potassium phosphate. A larger difference

Table 2. Appearance, texture and taste of sausages and hams $(\mathrm{N}=2)$. Appearance was evaluated by a threepoint, texture by a five-point and taste and flavour by a seven-point scale.

\begin{tabular}{lcccc}
\hline & Appearance /3 & Texture /5 & Taste and flavour /7 & Total /15 \\
\hline Sausages ${ }^{1)}$ & & & & \\
Sausage 1 & $2.3 \pm 0.4^{\mathrm{a}}$ & $3.5 \pm 0.7^{\mathrm{a}}$ & $4.3 \pm 0.4^{\mathrm{a}}$ & $10.5 \pm 0.7^{\mathrm{a}}$ \\
Sausage 2 & $3.0 \pm 0.0^{\mathrm{a}}$ & $4.0 \pm 0.7^{\mathrm{a}}$ & $4.5 \pm 0.0^{\mathrm{a}}$ & $11.5 \pm 0.7^{\mathrm{a}}$ \\
Sausage 3 & $2.8 \pm 0.4^{\mathrm{a}}$ & $3.8 \pm 0.4^{\mathrm{a}}$ & $5.0 \pm 0.0^{\mathrm{a}}$ & $11.5 \pm 0.7^{\mathrm{a}}$ \\
Sausage 4 & $3.0 \pm 0.0^{\mathrm{a}}$ & $3.8 \pm 0.4^{\mathrm{a}}$ & $5.0 \pm 0.0^{\mathrm{a}}$ & $11.8 \pm 0.4^{\mathrm{a}}$ \\
Hams & & & & \\
Ham 1 & $3.0 \pm 0.0^{\mathrm{b}}$ & $3.8 \pm 0.4^{\mathrm{b}}$ & $4.8 \pm 0.4^{\mathrm{b}}$ & $11.5 \pm 0.0^{\mathrm{b}}$ \\
Ham 2 & $3.0 \pm 0.0^{\mathrm{b}}$ & $4.0 \pm 0.0^{\mathrm{b}}$ & $4.3 \pm 0.4^{\mathrm{b}}$ & $11.3 \pm 0.4^{\mathrm{b}}$ \\
Ham 3 & $3.0 \pm 0.0^{\mathrm{b}}$ & $4.0 \pm 0.0^{\mathrm{b}}$ & $5.5 \pm 0.0^{\mathrm{b}}$ & $12.5 \pm 0^{\mathrm{b}}$ \\
Ham 4 & $3.0 \pm 0.0^{\mathrm{b}}$ & $4.0 \pm 0.0^{\mathrm{b}}$ & $4.8 \pm 0.4^{\mathrm{b}}$ & $11.8 \pm 0.4^{\mathrm{b}}$ \\
\hline
\end{tabular}

a same letter in the column means no significant difference between sausages

b same letter in the column means no significant difference between hams

Sausages ${ }^{1)}$ : Sausage 1, $1.0 \% \mathrm{NaCl}+$ sodium diphosphate mixture; Sausage 2, $1.2 \% \mathrm{NaCl}+$ tetrapotassium pyrophosphate; Sausage 3, 1.2\% NaCl + sodium diphosphate mixture; Sausage 4, 1.4\% NaCl + tetrapotassium pyrophosphate

Hams $^{2}$ : Ham 1, 1.4\% NaCl + sodium phosphate mixture; Ham 2, 1.4\% $\mathrm{NaCl}+$ potassium phosphate mixture; Ham 3, $1.8 \% \mathrm{NaCl}+$ sodium phosphate mixture; Ham 4, $1.8 \% \mathrm{NaCl}+$ potassium phosphate mixture 
Vol. 11 (2002): 199-207.

Table 3. Number of correct judgements in triangle tests.

\begin{tabular}{|c|c|c|c|}
\hline Samples & Number of judgements & $\begin{array}{c}\text { Number of correct } \\
\text { judgements }\end{array}$ & Significance leve \\
\hline \multicolumn{4}{|l|}{ Sausages $^{1)}$} \\
\hline Sausage 1 and Sausage 2 & 38 & 27 & $* * *$ \\
\hline Sausage 3 and Sausage 4 & 38 & 20 & $*$ \\
\hline \multicolumn{4}{|l|}{ Hams $^{2)}$} \\
\hline Ham 1 and Ham 2 & 36 & 14 & NS \\
\hline Ham 3 and Ham 4 & 36 & 16 & NS \\
\hline
\end{tabular}

$* \mathrm{P}<0.05 ; * * * \mathrm{P}<0.001 ; \mathrm{NS}$, not significant

Sausages $^{1)}$ : Sausage 1, $1.0 \% \mathrm{NaCl}+$ sodium diphosphate mixture; Sausage 2, $1.2 \% \mathrm{NaCl}+$ tetrapotassium pyrophosphate; Sausage 3, 1.2\% NaCl + sodium diphosphate mixture; Sausage $4,1.4 \% \mathrm{NaCl}+$ tetrapotassium pyrophosphate

$\mathrm{Hams}^{2)}$ : Ham 1, 1.4\% $\mathrm{NaCl}+$ sodium phosphate mixture; Ham 2, 1.4\% $\mathrm{NaCl}+$ potassium phosphate mixture; Ham 3, 1.8\% NaCl + sodium phosphate mixture; Ham 4, 1.8\% $\mathrm{NaCl}+$ potassium phosphate mixture

both in appearance and texture existed between sausages 1 and 2 than between sausages 3 and 4 (Table 2), which may be the reason rather than the bitter taste of potassium phosphate, why the former group could be distinguished more clearly from each other than the latter.

Puolanne and Ruusunen (1983) suggested that sodium chloride content should be at least $1.5 \%$ for acceptable texture of cooked sausage made with added phosphate. Barbut et al. (1988), in contrast, stated that sodium chloride levels below $2.0 \%$ are inadequate for stabilizing finely chopped meat batter; however, when only coarse chopping was used, a salt level of $1.5 \%$ is sufficient. In general, phosphate addition restores the emulsion stability of reduced-salt meat batters, with stability depending on the type of phosphate used. Knipe et al. (1985) have shown that decreasing the sodium chloride level from $1.5 \%$ to $0.75 \%$ increases the relative effects of phosphate type and level on emulsion stability. Therefore, attention should be given to the type of phosphate used when sodium reduction is desired. In this study, the lowest salt content used to prepare cooked sausage was more than $1 \%$. In addition, an acceptable texture required the use of alkaline pyrophosphate. Extra proteins, such as sodium caseinate and soya concentrate, were also used to stabilize the sausages (Mittal and Usborne 1985), because the salt levels used were very low (1.0 to $1.4 \%)$.

The flavour of a typical cooked ham is blander than the flavour of cooked sausage. Thus, it was expected that the potassium flavour should have been more noticeable in the cooked ham than in the sausage. In this study, in the triangle tests, hams 1 and 2, and 3 and 4 were compared separately. When hams 1 and 2 were compared, 14 out of 36 judgements were correct, and the corresponding figure for hams 3 and 4 was 16 out of 36 judgements (Table 3 ). The difference was not significant, i.e. the assessors were unable to distinguish the hams made with sodium phosphate from those made with potassium phosphate.

\section{Conclusions}

Very low-salt (i.e. $1.0-1.4 \% \mathrm{NaCl}$ ) meat products can be prepared provided that phosphates are added. Further reduction of sodium content 


\section{Ruusunen, M. et al. Sodium reduction in cooked meat products}

in low-salt meat products is possible by replacing sodium phosphate with potassium phosphate. The extent of sodium reduction depends on the phosphates used and their sodium content, being equivalent to a sodium content of $0.2 \% \mathrm{NaCl}$ or more. The replacement resulted in no adverse effects. Alkaline phosphates are also recommended in very low-salt products to minimize risk of purge.

Acknowledgements. This study has been supported by the National Technology Agency (Tekes) in Finland.

\section{References}

Amerine, M.A., Pangborn, R.M. \& Roessler, E.B. 1965. Principles of sensory evaluation of food. Academic Press Inc., New York and London. 602 p.

Barbut, S., Maurer, A.J. \& Lindsay, R.C. 1988. Effects of reduced sodium chloride and added phosphates on physical and sensory properties of turkey frankfurters. Journal of Food Science 53: 62-66.

EU directive 95/2/EY. Food additives, other than colourants and sweeteners.

Hamm, R. 1962. Über das Wasserbindungsvermögen des Säugetiermuskels. X Mitt. Der Einfluss von Salzen auf Proteinladung und Wasserbindungsvermögen. Zeitschrift für Lebensmittel Untersuchung und Forschung 116: 511-516.

Hamm, R. 1972. Kolloidchemie des Fleisches. Paul Parey, Berlin. 222 p.

Keeton, J.T., Foegeding, E.A. \& Patana-Anaka, C. 1984. A comparison of nonmeat proteins, sodium tripolyphosphate and processing temperature effects on physical and sensory properties of frankfurters. Journal of Food Science 49: 1462-1465, 1474.

Kivikari, R. 1996. Analysis of sodium in meat products using an Na-selective electrode. In: Proceedings of Meat Day Seminar 1996. University of Helsinki, Department of Meat Technology, Reports from Meat Technology. No. 536. p. 64-66. (in Finnish).

Knipe, C.L., Olson, D.G. \& Rust, R.E. 1985. Effects of selected inorganic phosphates, phosphate levels and reduced sodium chloride levels on protein solubility, stability and $\mathrm{pH}$ of meat emulsions. Journal of Food Science 50: 1010-1013.

Knipe, C.L., Rust, R.E. \& Olson, D.G. 1990. Some physical parameters involved in the addition of inorganic phosphates to reduced-sodium meat emulsion. Journal of Food Science 55: 23-25.

Lewis, D.F. 1979. Meat products. In: Vaughan, J.G. (ed.). Food microscopy. Academic Press, New York. p. 233.

Mittal, G.S. \& Usborne, W.R. 1985. Meat emulsion extenders. Food Technology 4: 121-130.

NMKL 1976. Nitrogen determination in foods and feeds according to Kjeldahl. Nordic Committee on Food Analysis No. 6. 3rd Edition.
Offer, G. \& Knight, P. 1988. The structural basis of water-holding in meat. Part 1: General principles and water uptake in meat processing. In: Lawrie, R. (ed.). Developments in Meat Science - 4. Elsevier Applied Science. London, New York.p. 63-172.

Puolanne, E. \& Ruusunen, M. 1983. Einfluss des Salzzusatzes auf das Wasserbindungsvermögen von des Fleisches in Brühwurst vershiedener Rezepturen. Fleischwirtschaft 63: 238-239.

Puolanne, E., Ruusunen, M.H. \& Vainionpää, J.I. 2001. Combined effects of $\mathrm{NaCl}$ and raw meat $\mathrm{pH}$ on water-holding in cooked sausage with and without added phosphate. Meat Science 58: 1-7.

Rust, R.E. \& Olson, D.G. 1982. Salt reduction in processed meats. Meat Processing 21: 76-80.

Ruusunen, M.H., Särkkä-Tirkkonen, M. \& Puolanne, E. 2000. Saltiness of coarsely ground cooked ham with reduced salt content. Agricultural and Food Science in Finland 10: 27-32.

SAS Institute Inc. 1989. SAS/STAT User's Guide. Version 6, Fourth edition, Vol. 2. Gary, NC. 846 p.

Shults, G.W., Russell, D.R. \& Wierbicki, E. 1972. Effect of condensed phosphates on $\mathrm{pH}$, swelling and water-holding capacity of beef. Journal of Food Science 37: 860-864.

Shults, G.W. \& Wierbicki, E. 1973. Effects of sodium chloride and condensed phosphates on the water-holding capacity, $\mathrm{pH}$ and swelling of chicken muscle. Journal of Food Science 38: 991-994.

Sofos, J.N. 1986. Use of phosphates in low-sodium meat products. Food Technology 40, 9: 52, 54-58, 60, 62, $64,66,68-69$.

Trout, G.R. \& Schmidt, G.R. 1986. Effect of phosphates on the functional properties of restructured beef rolls: the role of $\mathrm{pH}$, ionic strength, and phosphate type. Journal of Food Science 51: 1416-1423.

Trout, G.R. \& Schmidt, G.R. 1987. The effect of cooking temperature on the functional properties of beef proteins: the role of ionic strength, $\mathrm{pH}$, and pyrophosphate. Meat Science 20: 129-147.

Whiting, R.C. 1984. Addition of phosphates, proteins, and gums to reduced-salt frankfurter batters. Journal of Food Science 49: 1355-1357. 
Vol. 11 (2002): 199-207.

\title{
SELOSTUS
}

\section{Natriumpitoisuuden pienentäminen lihavalmisteissa korvaamalla natriumfosfaatti kaliumfosfaatilla}

\author{
Marita Ruusunen, Markku Niemistö ja Eero Puolanne \\ Helsingin yliopisto ja Lihateollisuuden Tutkimuskeskus
}

Suolan lisäksi natriumfosfaatti suurentaa lihavalmisteiden natriumpitoisuutta. Useat natriumfosfaatit sisältävät $30 \%$ natriumia. Tämän vuoksi tutkimuksessa selvitettiin, miten natriumfosfaatin korvaaminen kaliumfosfaatilla vaikuttaa leikkelemakkaran ja kinkkuleikkeen ominaisuuksiin. Tutkimuksessa valmistettiin neljä erilaista leikkelemakkaramassaa normaalia pienemmällä suolapitoisuudella. Massoissa 1 ja 2 tavoitenatriumpitoisuus oli $0,55 \mathrm{~g} \mathrm{Na} / 100 \mathrm{~g}$ sekä massoissa 3 ja 4 0,63 g Na/100 g. Muista valmistusaineista kuin suolasta ja natriumfosfaatista tuleva natriumin märä oli kaikissa resepteissä sama. Massoissa 1 ja 3 suolalisäykset olivat 1 ja $1,2 \%$, ja fosfaattina käytettiin natriumfosfaattia. Massoissa 2 ja 4 suolalisäykset olivat 1,2 ja $1,4 \% \mathrm{NaCl}$, ja fosfaattina käytettiin kaliumfosfaattia, jonka $\mathrm{pH}$ oli korkeampi kuin käytetyn natriumfosfaatin.

Tutkimuksessa valmistettiin myös neljä erilaista kinkkuleikettä. Kinkkuleikkeissä 1 ja 2 suolaa lisättiin 1,4\% ja kinkkuleikkeissä 3 ja 4 1,8\%. Kinkkuleikkeissä 1 ja 3 käytettiin natriumfosfaattia ja kinkkuleikkeissä 2 ja 4 kaliumfosfaattia, jonka $\mathrm{pH}$ arvo oli korkeampi kuin käytetyn natriumfosfaatin.

Tutkimuksessa todettiin, että fosfaattia on käytettävä, jos lihavalmisteet valmistetaan hyvin pienillä suolapitoisuuksilla $(1,0-1,4 \% \mathrm{NaCl})$. Lihavalmisteiden natriumpitoisuutta voidaan pienentää korvaamalla natriumfosfaatti kaliumfosfaatilla. Tällä tavoin aikaansaatu natriumpitoisuuden pieneneminen vastaa samaa natriumin määrää, jonka $0,2 \% \mathrm{NaCl}$ sisältää. Kaliumfosfaatin ei todettu aiheuttavan haittavaikutuksia makkaraan eikä keittokinkkuun. Hyvin pienen natriumpitoisuuden tuotteissa suositellaan käytettäväksi emäksistä kaliumfosfaattia, joka parantaa tuotteen vedensidontakykyä ja siten varmistaa hyvän rakenteen. 